\title{
BIODEGRADABILITAS POLIKARBOKSILAT DARI ASAM ALGINAT DAN TAPIOKA
}

\section{Biodegradability of Polycarboxylates from Alginic Acid and Tapioca}

\author{
Isananto Winursito \\ Balai Riset dan Standardisasi Industri Manado \\ e-mail: isananto@yahoo.com
}

Diterima: 25 Februari 2013, Disetujui: 30 April 2013

\begin{abstract}
ABSTRAK
Karbohidrat yang terdapat secara melimpah di alam dapat digunakan untuk membuat polikarboksilat fungsional dan biodegradabel yang dapat dipakai di berbagai bidang industri. Dikarboksilasi-sebagian telah dilakukan terhadap karbohidrat dalam asam alginat dan tapioka, menghasilkan polimer terdikarboksilasi dengan derajat dikarboksilasi 13-78 mol\%. Biodegradabilitas asam alginat dan tapioka terdikarboksilasi, dihitung berdasarkan kebutuhan oksigen untuk aktivitas biokimia (BOD), tergantung pada derajat dikarboksilasi. Asam alginat dan tapioka terdikarboksilasi dengan sisa gugus glukopiranosa yang tinggi dapat terdegradasi dengan baik. Asam alginat terdikarboksilasi pada derajat dikarboksilasi 56 mol\% sudah tidak mengalami biodegradasi lagi, namun tapioka terdikarboksilasi masih dapat mengalami biodegradasi sampai derajat dikarboksilasi $74 \mathrm{~mol} \%$.
\end{abstract}

Kata Kunci: Biodegradabilitas, polikarboksilat, asam alginat, tapioka, dikarboksilasi

\section{ABSTRACT}

Abundantly occurring carbohydrates in nature can be used to obtain functional and biodegradable polycarboxylate for its application in various industrial fields. Partiallydicarboxylated of carbohydrate in alginic acid and tapioca with dicarboxylation degree from 13 to $78 \mathrm{~mol} \%$ were prepared. The biodegradability of dicarboxylated alginic acid and tapioca, evaluated by biochemical oxygen demand (BOD), depended on dicarboxylation degree. Dicarboxylated alginic acid and tapioca containing high remaining glucopyranose groups showed excellent biodegradation, though dicarboxylated alginic acid with the dicarboxylation degree of $56 \mathrm{~mol} \%$ was no longer biodegradable. However, dicarboxylated tapioca was still biodegrade up to the dicarboxylation degree of $74 \mathrm{~mol} \%$.

Keywords: Biodegradability, polycarboxylate, alginic acid, tapioca, dicarboxylation

\section{PENDAHULUAN}

Penelitian dan publikasi tentang polimer yang larut dalam air dan bersifat biodegradabel banyak dilakukan di berbagai bidang seperti untuk keperluan kedokteran (Luten et.al 2003, Nair et.al, 2007), farmasi (Park et.al, 2005; Gao et.al, 2003), makanan (Nussinovitch, 2003), bahan pembersih (Malik, 2008) dan plastik (Anonim, 2002). Polimer yang larut dalam air digunakan di industri pengolahan air, pelapisan (coating), textile sizing, cat, pembersih (sabun, deterjen), dan lain-lain.

Penggunaan sodium tripolifosfat (STPP) dalam industri pembersih yang berfungsi sebagai builder, suatu bahan pengikat garam-garam yang larut dalam air, dapat menyebabkan ketidakseimbangan dalam lingkungan sehingga dapat mengakibatkan kematian pada tumbuhan di perairan sebagai akibat dari terjadinya eutrofikasi (Conley, 2009; Jeffri, 2011). Oleh karena itu untuk menjaga kelestarian lingkungan perlu dicari bahan pengganti STPP yang mempunyai fungsi sama namun bersifat ramah lingkungan.

Telah dilaporkan bahwa polikarboksilat dengan bobot molekul tinggi dapat digunakan sebagai polimer fungsional yang larut dalam air, termasuk sebagai dispersant dan 
builder pada bahan pembersih (Freeman and Bender, 1993). Namun, polikarboksilat bobot molekul tinggi tersebut pada umumnya sangat resisten terhadap biodegradasi, yang justru merupakan kriteria penting dalam pemakaiannya di industri dalam skala besar. Dengan pemikiran bahwa jika dalam polimer tersebut masih terdapat bagian yang degradabel, maka diharapkan bahan tersebut dapat diterima sebagai polimer fungsional yang biodegradabel untuk menggantikan STPP. Karbohidrat dapat digunakan sebagai bahan dasar untuk pembuatan poli(karboksilat) bobot molekul tinggi karena bahan tersebut murah, mudah didapat, dapat diperbaharui (renewable) dan merupakan material yang biodegradabel (Swift, 1995).

Alginat dapat merupakan salah satu sumber karbohidrat yang dapat diperoleh dari perairan di daerah tropis dan subtropis. Alginat, yang merupakan asam poliuronat linier dan tersusun dari poli( $\beta$-D-asam manuronat) dan poli( $\alpha-L-a s a m$ guluronat), terdapat dalam algae laut coklat (Phaeophyta). Algae tersebut termasuk dalam marga Ascophyllum, Macrocystis, Laminaria, Durvillaea, Ecklonia, Laessonia, Sargassum dan Turbinaria (Yulianto, 2007, Yunisa, 2007).

Di sisi lain, pati juga merupakan bahan yang terdapat secara melimpah dan dapat merupakan salah satu alternatif bahan dalam pembuatan polikarboksilat bobot molekul tinggi. Pati pada umumnya terdiri dari amilosa dan amilopektin. Amilosa merupakan makromolekul dengan rantai linier tersusun dari $(1,4)$ - $\alpha$-D-glukopiranosa, sedangkan amilopektin merupakan struktur bercabang, mempunyai $(1,4)$ - $\alpha$ di antara unit glukopiranosa dan ikatan $(1,6)-\alpha$ pada percabangannya. Komposisi amilosa dan amilopektin dalam pati mempunyai variasi yang sangat besar, tergantung pada asal dan jenis tanaman, kondisi geografis, waktu pemanenan, kesuburan tanah, proses dalam pembuatan pati, dan lain lain. Namun secara umum di dalam pati terkandung amilosa sebanyak $20-25 \%$ dan amilopektin sebanyak 75-80\%. (Anonim, 2013).

Akhir-akhir ini di Indonesia varietas unggulan Singkong Gajah semakin populer. Singkong yang pada awalnya dikembangkan di Kalimantan Timur ini dapat menghasilkan umbi dengan berat sembilan kali dari berat singkong biasa (Pangendongan, 2011). Dengan produktivitas singkong yang tinggi ini diharapkan pemakaian singkong/tapioka untuk keperluan industri nonmakanan tidak lagi menjadi keluhan bagi para ahli dan komunitas pemerhati pangan.

Mempelajari biodegradabilitas suatu material masih merupakan hal yang relatif baru bagi Indonesia jika dibandingkan dengan negara-negara maju. Beberapa produk yang saat ini beredar di pasaran telah diklaim sebagai bersifat degradabel, namun belum didukung dengan penelitian, pembuktian, ataupun penjelasan secara ilmiah yang memadai (Winursito, 2012). Pada penelitian ini dilakukan sintesa polikarboksilat dari alginat, yang merupakan hasil dari algae/rumput laut, dan pati tapioka dari singkong dengan reaksi karboksilasisebagian dalam upaya untuk tetap menyisakan unit glukopiranosa. Selanjutnya, dari polikarboksilat alginat dan pati yang dihasilkan dari sintesa ini dilakukan uji biodegradasi untuk mempelajari karakter biodegradabilitas dari masing-masing bahan.

\section{METODOLOGI PENELITIAN}

\section{Bahan dan Alat}

Asam alginat yang berasal dari Macrocystis pyrifera diperoleh dari Aldrich Chemical Co., sedangkan tapioka dari Manihot utilissima P., Manihot esculenta, diperoleh dari pati tapioka yang ada di pasaran. Bahan-bahan kimia lain untuk proses dan pengujian dengan kemurnian tinggi diperoleh dari supplier bahan kimia.

Untuk melihat struktur atom karbon dari polimer yang dihasilkan, digunakan ${ }^{13} \mathrm{C}$ NMR model JNM-FX90A (JEOL Ltd., Tokyo,Japan). Pengukuran bobot molekul (Mn) dan distribusi bobot molekul (Mw/Mn) dilakukan dengan sistem gel permeation chromatography (GPC) dengan kolom GPC komersial (TSK gel G5000PW + G2500PW, Tosoh Co., Ltd). Sedangkan pengamatan biodegradasi dilakukan dengan pengukuran BOD (biochemical oxygen demand) menggunakan alat BOD-tester (Model 200 F; TAITEC Corp., Koshigaya-Shi, Japan). 


\section{Pelaksanaan Penelitian}

\section{Sintesa Alginat dan Tapioka Terdikarboksilasi}

Reaksi dikarboksilasi-sebagian dari asam alginat maupun tapioka bertujuan untuk membuat polimer-polimer ini dapat larut dalam air akibat terbentuknya gugus karboksilat, namun tetap menyisakan unit glukopiranosa agar tetap bersifat biodegradabel. Beberapa tingkatan atau derajat dikarboksilasi dibuat dengan konversi-sebagian visinal diol dari unit glukopiranosa menjadi dikarboksilat melalui dialdehida, seperti terdapat pada Gambar 1. Pembuatan asam alginat terdikarboksilasi yang mempunyai bobot molekul 14.000 dan derajat dikarboksilasi $24 \mathrm{~mol} \%$ digunakan sebagai tipikal contoh sintesis.

Asam alginat ( 3 gram) disuspensikan ke dalam $60 \mathrm{ml}$ larutan natrium peryodat (NalO4) $0,05 \mathrm{M}$, diaduk pada suhu $4^{\circ} \mathrm{C}$ dalam gelap selama 24 jam. Setelah itu $\mathrm{pH}$ larutan diatur menjadi 10 dengan menggunakan larutan $\mathrm{NaOH} 3 \mathrm{M}$, dan bagian yang tidak larut dihilangkan dengan penyaringan. Filtrat yang diperoleh kemudian dilakukan dialisa dalam air untuk menghilangkan fraksi berat molekul rendah, menggunakan tube dialisis. Larutan yang telah didialisa diuapkan airnya sehingga dihasilkan diformil asam alginat. Selanjutnya, senyawa ini disuspensikan ke dalam $90 \mathrm{ml}$ air, gas nitrogen dialirkan ke dalamnya pada suhu $0^{\circ} \mathrm{C}$ selama 30 menit, dan ditambahkan larutan yang dibuat dari 15,5 gram natrium klorit $\left(\mathrm{NaClO}_{2}\right)$ dalam $52 \mathrm{ml}$ air. $\mathrm{pH}$ larutan diatur supaya menjadi 4 dengan menggunakan asam asetat pekat dan larutan terus diaduk menggunakan stirrer pada suhu $20^{\circ} \mathrm{C}$ selama 24 jam. Setelah suhu dinaikkan sampai $50^{\circ} \mathrm{C}$ dan reaksi dilanjutkan selama 1 jam, gas nitrogen dialirkan sampai warna larutan hilang. Dengan larutan $\mathrm{NaOH} 3 \mathrm{M}, \mathrm{pH}$ larutan dinaikkan kembali menjadi 10 , kemudian larutan dituang perlahan-lahan ke dalam 400 $\mathrm{ml}$ etanol dengan pengadukan untuk mendapatkan polimer. Setelah etanol dibuang, endapan polimer dilarutkan dengan $50 \mathrm{ml}$ air dan kembali dilakukan dialisa dalam air selama 3 hari. Presipitat yang tidak larut dihilangkan dengan penyaringan dan filtrat dikeringkan secara freeze-drying, menghasilkan asam alginat terdikarboksilasi berupa powder putih dengan kandungan dikarboksilat sebesar $24 \mathrm{~mol} \%$, bobot molekul 14.000 dan distribusi bobot molekul, $(\mathrm{Mw} / \mathrm{Mn})=2,0$.

Asam alginat yang lain serta tapioka terdikarboksilasi, dibuat dengan prosedur yang sama namun dengan beberapa konsentrasi natrium peryodat yang berbeda untuk mendapatkan polikarboksilat dengan berbagai derajat dikarboksilasi. Hasil dari seluruh percobaan dan analisis datanya disajikan dalam Tabel 1.

\section{Pengujian biodegradasi}

Pengujian biodegradasi menjadi hal yang sangat penting dalam mempelajari sifat biodegradabilitas suatu materi. Dalam penelitian ini dilakukan pengujian BOD (biochemical oxygen demand) dan perhitungan TOD (theoretical oxygen demand) untuk dapat menghitung besaran biodegradasinya.

BOD ditentukan berdasarkan metoda konsumsi oksigen, mengacu pada OECD Guidelines for Testing of Chemicals pada suhu $25^{\circ} \mathrm{C}$ (OECD, 1981). Sebagai sumber mikrobia digunakan lumpur aktif (activated sludge) yang diambil dari suatu instalasi pengolahan akhir limbah (IPAL). Larutan sampel disiapkan dengan konsentrasi $0,1 \%$ (1000 ppm), diambil sebanyak $5 \mathrm{ml}$ dan dimasukkan ke dalam $195 \mathrm{ml}$ larutan medium di dalam botol inkubasi. Botol kemudian ditutup dengan unit penyerap $\mathrm{CO}_{2}$ yang telah diisi dengan larutan $\mathrm{NaOH}$ jenuh. Pipa keluaran yang terdapat pada tutup dihubungkan ke unit manometer. Botol inkubasi dimasukkan ke dalam water bath, dikondisikan agar suhu tetap pada $25^{\circ} \mathrm{C}$.

Pada uji BOD ini, oksigen yang dibutuhkan untuk metabolisme mikrobia aerob hanya tersedia pada head space botol inkubasi. Berhubung gas $\mathrm{CO}_{2}$ yang dilepas dari metabolisme mikrobia diserap oleh larutan $\mathrm{NaOH}$ jenuh maka kenaikan permukaan air pada unit manometer menunjukkan konsumsi oksigen oleh mikrobia. Dengan mengamati perubahan permukaan air pada buret, dan mengoreksinya dengan larutan kontrol, maka konsumsi oksigen dapat 
diketahui, dan BOD dapat dihitung dari persamaan (1):

$$
\mathrm{BOD}=\frac{\mathrm{A}-\mathrm{B}}{22,4 \times 103 \times \frac{298}{273}} \times \frac{32 \times 10^{3}}{\mathrm{C}}
$$

$A=$ volume oksigen yang dikonsumsi oleh larutan sampel $(\mathrm{ml})$

$B=$ volume oksigen yang dikonsumsi oleh larutan kontrol $(\mathrm{ml})$

$\mathrm{C}=$ berat dari sampel yang diuji (gram)

TOD (theoretical oxygen demand), mempunyai satuan $\mathrm{mg}$ oksigen/gram sampel, didefinisikan sebagai berat konsumsi oksigen jika 1 gram senyawa termineralisasi menjadi $\mathrm{CO}_{2}$ dan $\mathrm{H}_{2} \mathrm{O}$. Penentuan TOD, untuk senyawa secara umum, dapat dilakukan berdasar persamaan (2):

$\mathrm{C}_{\mathrm{k}} \mathrm{H}_{\mathrm{m}} \mathrm{O}_{\mathrm{n}}+\mathrm{p} \mathrm{O}_{2} \rightarrow \mathrm{k} \mathrm{CO}_{2}+\frac{\mathrm{m}}{2} \mathrm{H}_{2} \mathrm{O}$

TOD dan biodegradasi dapat dihitung dari persamaan (3):

$$
\begin{aligned}
& \mathrm{p}=\frac{1}{2}\left(2 \mathrm{k}+\frac{\mathrm{m}}{2}-\mathrm{n}\right) \\
& \mathrm{TOD}=\frac{\mathrm{p} \times 32 \times 10^{3}}{\mathrm{BM}} \\
& =\frac{\left(2 \mathrm{k}+\frac{\mathrm{m}}{2}-\mathrm{n}\right) \times 16.10^{3}}{\mathrm{BM}}
\end{aligned}
$$

$\mathrm{BM}=$ bobot molekul dari unit ulangan pada polimer.

$$
\text { Biodegradasi }=\frac{\mathrm{BOD}}{\mathrm{TOD}} \times 10 \%
$$

\section{HASIL DAN PEMBAHASAN}

\section{Pembuatan asam alginat dan tapioka terdikarboksilasi}

Asam alginat maupun pati tapioka merupakan sumber karbohidrat yang terdapat di daerah tropis sampai sub tropis, dan keduanya merupakan polimer yang tersusun dari unit-unit glukopiranosa. Asam alginat tersusun dari unit-unit glukopiranosa dengan rantai linier, sedangkan tapioka mempunyai rantai linier (amilosa) maupun bercabang (amilopektin).

Reaksi dikarboksilasi-sebagian dari asam alginat maupun tapioka dengan beberapa tingkatan atau derajat dikarboksilasi dibuat dengan oksidasisebagian visinal diol dari unit glukopiranosa menggunakan natrium peryodat menjadi dialdehida, dan selanjutnya dilakukan oksidasi lebih lanjut menggunakan natrium klorit menghasilkan dikarboksilat, seperti diperlihatkan pada Gambar 1.

Derajat dikarboksilasi dikendalikan dengan konsentrasi natrium peryodat. Semakin banyak natrium peryodat yang digunakan maka semakin banyak dikarboksilat yang terbentuk sehingga derajat dikarboksilasi semakin tinggi. Meskipun demikian reaksi ini juga membawa akibat terjadinya pemutusan rantai-rantai polimer. Semakin banyak pengoksidasi yang digunakan maka semakin besar kemungkinan terjadinya pemutusan rantai polimer. Hal ini ditunjukkan dari terjadinya penurunan bobot molekul (Mn) serta distribusi bobot molekul (Mw/Mn), seperti tampak pada Tabel 1. Pada konsentrasi natrium peryodat rendah dihasilkan asam alginat maupun tapioka terdikarboksilasi dengan bobot molekul di atas 20.000 , sedangkan pada konsentrasi natrium peryodat yang paling tinggi bobot molekulnya di sekitar 11.000. Pemotongan rantai polimer juga mengakibatkan variasi bobot molekul polimer menjadi lebih kecil, seperti ditunjukkan dari sebaran bobot molekul (Mw/Mn) polimer yang menjadi semakin sempit (narrow) pada penggunaan natrium peryodat yang semakin banyak. Data polimer hasil dikarboksilasi asam alginat dan tapioka secara lengkap disajikan dalam Tabel 1 .

Untuk mengkonfirmasi telah terbentuknya dikarboksilat maupun terdapatnya sisa unit glukopiranosa, dilakukan analisa menggunakan ${ }^{13} \mathrm{C}$ NMR terhadap sampel AT14000(24), sebagai representasi, dengan hasil seperti yang disajikan dalam Gambar 2. Bagian dari glukopiranosa yang telah terdikarboksilasi menghasilkan dua gugus karboksilat (-COONa) baru. Gugus ini bertanggung jawab atau menentukan kelarutan dari alginat maupun tapioka terdikarboksilasi di dalam air. 


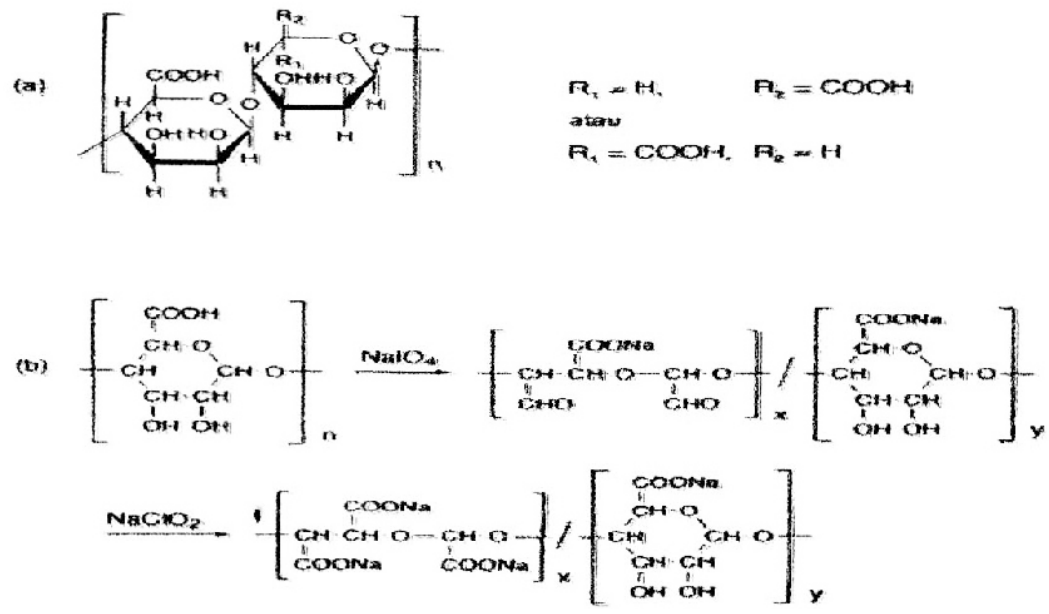

Gambar 1 : Struktur glukopiranosa (a) dan reaksi dikarboksilasi-sebagian asam alginat dan tapioka (b).

Tabel 1. Konsentrasi $\mathrm{NalO}_{4}$ dan hasil dikarboksilasi sebagian dari asam alginat dan tapioka.

\begin{tabular}{|l|c|c|c|c|c|}
\hline Senyawa a) & $\begin{array}{c}\text { Konsentrasi } \\
\mathrm{NalO}_{4}(\mathrm{M})\end{array}$ & $\begin{array}{c}\text { Hasil } \\
(\%)\end{array}$ & $\begin{array}{c}\text { Kandungan dikarboksilat } \\
(\mathrm{Mol} \%)\end{array}$ & $\mathrm{Mn}$ & $\mathrm{Mw} / \mathrm{Mn}$ \\
\hline AT-24600(13) & 0.0175 & 94 & 13 & 24600 & 2.3 \\
AT-14000(24) & 0.05 & 63 & 24 & 14000 & 2.0 \\
AT-11000(42) & 0.12 & 64 & 42 & 11000 & 1.9 \\
AT-12800(53) & 0.19 & 65 & 53 & 12800 & 1.8 \\
AT-12500(56) & 0.26 & 63 & 56 & 12500 & 1.8 \\
AT-11600(61) & 0.33 & 55 & 61 & 11600 & 1.9 \\
\hline TT-21100(8) & 0.015 & 80 & 8 & 21100 & 6.3 \\
TT-17800(24) & 0.05 & 77 & 24 & 17800 & 2.3 \\
TT-15800(45) & 0.10 & 67 & 45 & 15800 & 8.0 \\
TT-15900(73) & 0.20 & 79 & 73 & 15900 & 2.3 \\
TT-11400(78) & 0.30 & 74 & 78 & 11400 & 1.6 \\
\hline
\end{tabular}

a) Kode polimer: angka pertama menunjukkan bobot molekul rata-rata $(\mathrm{Mn})$, diikuti dengan angka di dalam kurung yang menunjukkan kandungan dikarboksilat ( $\mathrm{mol} \%$ ).

AT = asam alginat terdikarboksilasi; TT = tapioka terdikarboksilasi

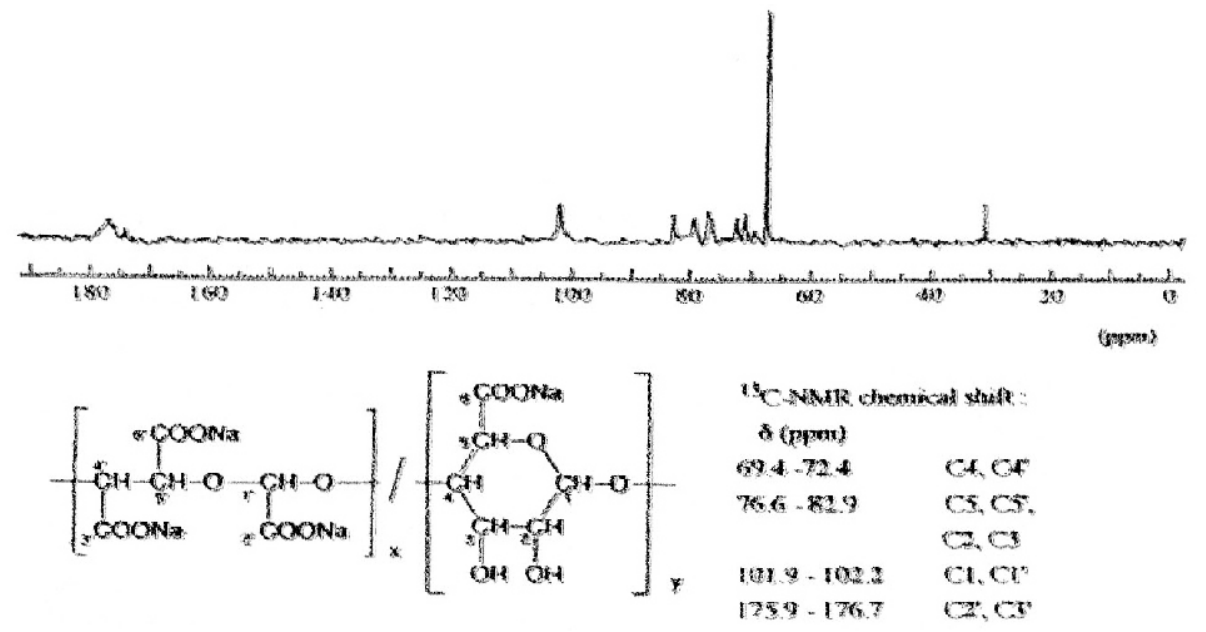

Gambar 2 : Spektrum ${ }^{13} \mathrm{C}$ NMR dan data ingsutan kimia (chemical shift) dari AT-14000(24). 


\section{Biodegradabiltas asam alginat dan tapioka terdikarboksilasi}

Pengujian biodegradasi dilakukan berdasarkan konsumsi oksigen oleh mikrobia dalam proses mineralisasi, atau yang biasa disebut dengan BOD (biochemical oxygen demand). Selanjutnya, biodegradasi dihitung menurut perbandingan BOD dengan TOD.

Asam alginat dan tapioka terdikarboksilasi yang masih mengandung unit glukopiranosa dapat terbiodegradasi oleh mikrobia. Gambar 3, yang menjelaskan hubungan antara biodegradasi dan derajat dikarboksilasi, menunjukkan bahwa biodegradabilitas asam alginat dan tapioka yang telah terdikarboksilasi dipengaruhi oleh jumlah unit glukopiranosa dalam polimer. Semakin rendah derajat dikarboksilasi, yang berarti semakin tinggi sisa unit glukopiranosanya, menunjukkan biodegradasi yang semakin tinggi. Hal ini mengindikasikan bahwa unit glukopiranosa bertindak sebagai gugus yang biodegradabel, dan sebaliknya bagian yang mengalami dikarboksilasi relatif tahan terhadap biodegradasi oleh mikrobia.

Jika dibandingkan biodegradabilitas antara asam alginat dengan tapioka, tampak bahwa biodegradabilitas asam alginat terdikarboksilasi (AT) pada derajat dikarboksilasi yang rendah menunjukkan biodegradabilitas yang relatif lebih tinggi dari pada tapioka terdikarboksilasi (TT). Namun pada derajat dikarboksilasi di atas $40 \%$ biodegradabilitas dari asam alginat terdikarboksilasi lebih rendah dari pada tapioka terdikarboksilasi. Oksidasi-sebagian terhadap unit glukopiranosa yang menghasilkan gugus terdikarboksilasi pada asam alginat dan tapioka berlangsung secara acak. Asam alginat terdikarboksilasi tersusun dari rantai linier, dan pada derajat dikarboksilasi rendah menunjukkan biodegradasi yang sangat baik karena mikrobia dapat menggunakan blok-blok kopolimer yang mengandung unit glukopiranosa untuk metabolismenya. Namun pada derajat dikarboksilasi tinggi tampaknya mikrobia tidak dapat memanfaatkan unit glukopiranosa yang terletak secara bukan blok di antara gugus-gugus dikarboksilat untuk metabolismenya. Bahkan pada derajat dikarboksilasi $56 \mathrm{~mol} \%$ biodegradasi asam alginat terdikarboksilasi tidak berlangsung.

Tapioka sebagian besar tersusun dari amilopektin (75-80 \%) yang mempunyai struktur bercabang (Anonim, 2013). Pada tapioka terdikarboksilasi dengan derajat dikarboksilasi rendah, panjang dari blok kopolimer yang mengandung unit glukopiranosa diduga lebih pendek karena tersebar pada rantai-rantai percabangannya, sehingga biodegradasi tapioka terdikarboksilasi pada derajat dikarboksilasi yang sama dengan asam alginat terdikarboksilasi menjadi lebih rendah. Di lain pihak, terjadinya degradasi pada amilopektin dapat menyebabkan terputusnya percabangan-percabangan, yaitu ikatan $(1,6)-\alpha$. Masing-masing ujung rantai yang baru dapat dikonsumsi oleh mikrobia sehingga pada derajat dikarboksilasi yang relatif tinggi pun, sampai $78 \mathrm{~mol} \%$, biodegradasi masih dapat berlangsung.

Biodegradabilitas dari asam alginat terdikarboksilasi (AT) dengan tapioka terdikarboksilasi (TT), ditentukan dari BOD (biochemical oxygen demand) dan TOD (theoretical oxygen demand), sebagai fungsi dari derajat dikarboksilasi (Gambar 3). Pengujian dilakukan dengan BOD tester pada suhu $25^{\circ} \mathrm{C}$, menggunakan lumpur aktif sebagai sumber mikrobia.

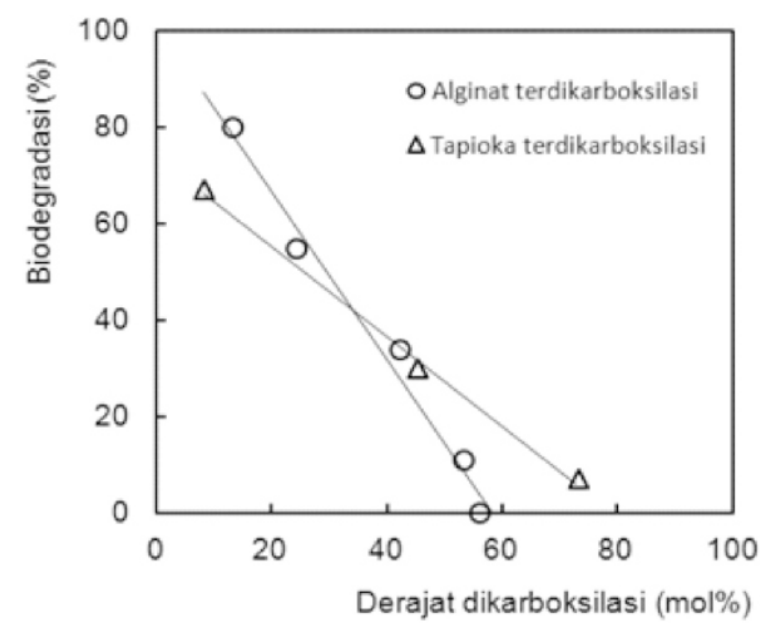

Gambar 3: Biodegradabilitas dari asam alginat terdikarboksilasi (AT) dengan tapioka terdikarboksilasi (TT)

Dari publikasi sebelumnya (Winursito, 2012), menyatakan bahwa tidak terdapat perbedaan di antara biodegradasi pati terdikarboksilasi yang berasal dari jagung, 
tapioka dan sagu. Dengan demikian, pada karbohidrat terdikarboksilasi dalam penelitian ini, terlihat rantai polimer bercabang lebih berpeluang untuk mengalami biodegradasi dibanding rantai polimer dengan struktur linier.

\section{Degradasi hidrolitik}

Melihat bobot molekul rata-rata dan distribusi bobot molekul dari polimer dengan menggunakan GPC sebelum dan sesudah uji biodegradasi merupakan salah satu metoda untuk mengamati cara pemotongan rantai polimer sekaligus mengevaluasi keseluruhan degradasi yang terjadi pada polimer.

Untuk mengetahui kemungkinan terjadinya degradasi secara hidrolitik nonenzimatik (degradasi oleh adanya air, dan bukan akibat adanya mikrobia) terhadap polimer, maka telah dilakukan juga pengujian degradasi pada $\mathrm{pH} 5$ menggunakan salah satu sampel asam alginat terdikarboksilasi. Sampel dengan konsentrasi $400 \mathrm{mg} / \mathrm{liter}$ dibuat dengan melarutkan polimer pada buffer asetat $0,1 \mathrm{M}$ yang telah disterilkan. Suhu dijaga konstan pada $30{ }^{\circ} \mathrm{C}$ dan dilakukan dalam kondisi gelap untuk mencegah kemungkinan terjadinya degradasi hidrolitik yang disebabkan oleh adanya cahaya. Degradasi hidrolitik polimer dianalisa dengan mengamati profil bobot molekul dan distribusinya.

Hasil degradasi hidrolitik sampel AT11600(61), seperti terdapat pada Gambar 4, menunjukkan bahwa dalam masa inkubasi 10 dan 30 hari, profil dari bobot molekul telah bergeser ke arah bobot molekul rata-rata yang lebih rendah dengan posisi puncak yang relatif tetap. Hal ini mengindikasikan bahwa telah terjadi pemutusan rantai polimer sehingga polimer terputus menjadi bagian-bagian yang lebih pendek dan bobot molekul yang semakin menurun. Dari profil GPC tersebut tampak bahwa bobot molekul rata-rata polimer $(\mathrm{Mn})$ telah menurun dari belasan ribu menjadi berada pada orde beberapa ribu. Di lain pihak, luas area yang relatif sama menunjukkan bahwa distribusi bobot molekul (Mw/Mn) relatif tetap.

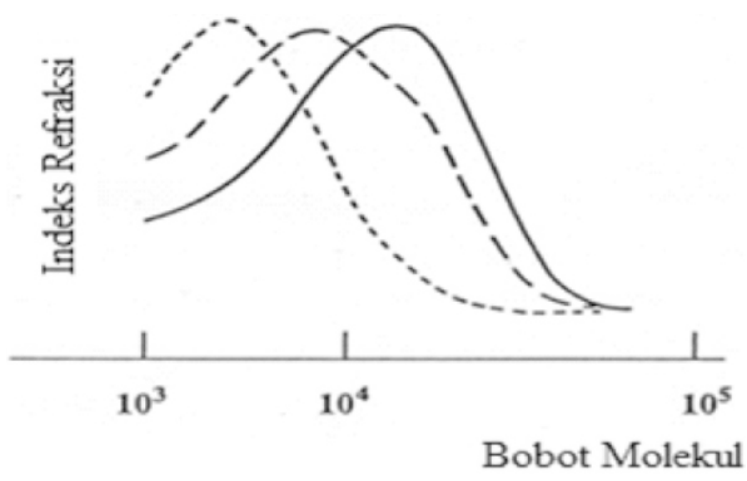

Keterangan: $\quad$, 0 hari, -- -- , 10 hari, ---, 30 hari

Gambar 4 :

Degradabilitas dari asam alginat terdikarboksilasi AT11600(61) sebelum dan sesudah degradasi hidrolitik pada $\mathrm{pH} 5$ dan suhu $30^{\circ} \mathrm{C}$ di dalam kondisi gelap.

Dengan mengamati bahwa rantai polimer juga dapat mengalami hidrolisa di dalam air maka diduga kedua mekanisme degradasi yaitu hidrolisa dan biodegradasi dalam penelitian ini, telah berlangsung secara sinergis. Rantai polimer terpotong menjadi molekul yang lebih kecil, sehingga dapat terasimilasi ke dalam sel mikrobia dan digunakan oleh mikrobia untuk metabolismenya (Narayan, 2009, Narayan, 2011).

Pada pengujian biodegradasi, profil GPC menunjukkan bahwa telah terjadi biodegradasi sehingga rantai polimer telah terpotong-potong menjadi bagian-bagian yang sangat pendek. Pada derajat dikarboksilasi rendah, baik pada alginat maupun tapioka terdikarboksilasi, praktis semua rantai polimer telah habis terpotong. Dilain pihak, pada derajat dikarboksilasi yang relatif tinggi, masih terdapat sisa polimer dalam jumlah yang tidak terlalu besar seperti yang ditunjukkan dengan masih adanya puncak (peak) setelah perlakuan biodegradasi selama 28 hari tersebut. 


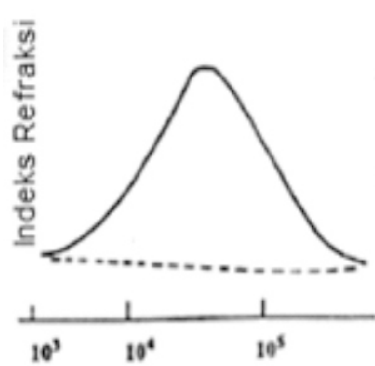

AT. $24600(13)$

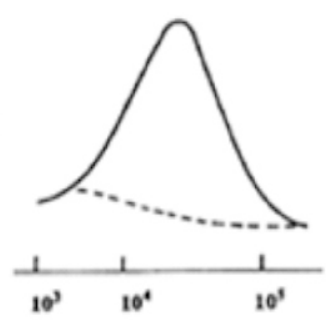

AT-12800(53)

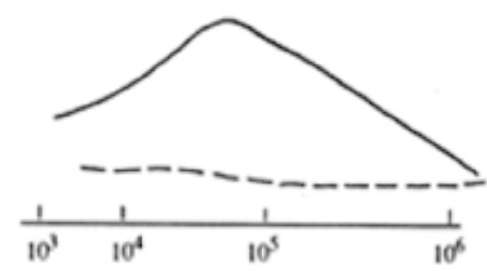

$\pi \cdot 21100(8)$

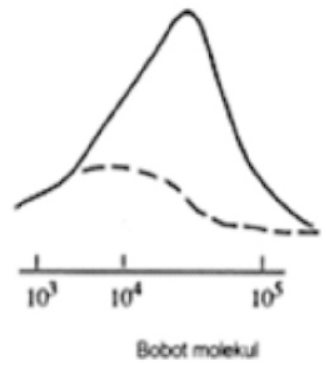

$\pi \cdot 15000(73)$

Keterangan: — 0 hari $\quad--, 28$ hari

Gambar 5: Profil GPC dari beberapa alginat dan tapioka terdikarboksilasi (AT dan TT) sebelum dan sesudah biodegradasi selama 28 hari.

\section{KESIMPULAN}

Berdasarkan hasil penelitian ini, dapat disimpulkan bahwa:

1. Dikarboksilasi-sebagian asam alginat dan tapioka menghasilkan polimer yang dapat larut dalam air. Gugus dikarboksilat menentukan kelarutan polimer di dalam air, sedangkan unit glukopiranosa menentukan biodegradabilitas polimer.

2. Semakin tinggi derajat dikarboksilasi mengakibatkan biodegradasi polimer semakin rendah. Asam alginat terdikarboksilasi mengalami biodegradasi sampai derajat dikarboksilasi sekitar $60 \mathrm{~mol} \%$, sedangkan tapioka masih mengalami biodegradasi sampai derajat dikarboksilasi sedikit di atas $70 \mathrm{~mol} \%$.

3. Pada uji biodegradasi juga dapat terjadi degradasi hidrolitik, sehingga dimungkinkan hidrolisa dan biodegradasi berlangsung secara sinergis.

\section{DAFTAR PUSTAKA}

Anonim. 2002. Plastic Film to Promote Grass Growing on Barren Landscapes. Materials World, Vol. 10, No. 8, 36.

Anonim. 2013. Starch, http://en.wikipedia. org/wiki/Starch.
Conley, D.J., Paerl, H.W., Howarth, R.W., Boesch, D.F., Seitzinger, S.P., Havens, K.E., Lancelot, C., Likens, G.E. 2009. Controlling Eutrophication: Nitrogen and Phosphorus. Science. Vol. 323, 1014-1015, 20 February 2009.

Freeman, M.B., Bender, T.M. 1993. An Environmental Fate and Safety Assessment or a Low Molecular Weight Polyacrylate Detergent Additive. Environ, Technol., 14, 101.

Gao, C., Xu, Y., Yan D., Chen, D. 2003. Water-soluble Degradable Hyperbranched Polyesters: Novel Candidates for Drug Delivery?. Biomacromolecules, Vol. 4, 704.

Jeffry. 2011. Eutrofikasi. http://jeffri022. student.umm.ac.id/2011/04/12/eutrofik asi/. Diakses 6 Maret 2013.

Luten, J., Steenis, J.H., Someren, R., Kemmink, J., SchuurmansNieuwenbroek, N.M.E., Koning, G.A., Crommelin, D.J.A., Nostrum, C.F., Hennink, W.E. 2003. Water-soluble B i odegrad a ble C a tion i c Polyphosphazenes for Gene Delivery, J. of Controlled Release, 89, p. 483.

Malik, I. 2008. http://iwanmalik.wordpress. com/2008/05/14/mau-deterjen/ 
Nair, L.S., Laurencin, C.T. 2007. Biodegradable Polymers as Biomaterials. Polymers in Biomedical Applications, Vol. 32, 8-9, p.762.

Narayan, R. 2009. Fundamental Principles and Concepts of Biodegradability Sorting through the facts, hypes, and claims of biodegradable plastics in the marketplace. BioPlastics magazine $\left(\begin{array}{lllll}0 & 1 & / & 0 & 9\end{array}\right) \quad$ vol $\quad 4$; www.bioplasticsmagazine. com

Narayan, R. 2011. Science behind compostable plastics - ASTM standards. Presentation at USCC $19^{\text {th }}$ Annual conference. January 26, 2011.

Nussinovitch, A. 2003. Water Soluble Polymer Applications in Foods, Blackwell Science Ltd, Oxford, UK.

OECD. 1981. OECD Guidelines for Testing of Chemicals, 301C, Modified MITI Test. Organization for Economic Cooperation and Development (OECD), Paris.

Pangendongan, O.R. 2011 Ristono, dari Varietas Singkong Gajah untuk A I t e r n a $t$ if B B M. http://lemlit.unmul.ac.id/index.php?p=3 $\& b=16 \& r=1$, admin, 1 Mei 2011. Diakses 2 Mei 2011
Park, J.H., Ye, M., Park, K. 2005. Biodegradable Polymers for Microencapsulation of Drugs, Molecules, Vol. 10, p. 146.

Swift, G. 1995. Opportunities for Environmentally Degradable Polymers. J. Macromol. Sci. - Pure Appl. Chem., A $32(4), 641$.

Winursito, I. 2012. Biodegradable and Water-Soluble Polycarboxylates Derived from Starch. Majalah Kulit, Karet dan Plastik. 28(1): 1-7.

Yulianto, K. 2007. Pengaruh Konsentrasi Natrium Hidroksida Terhadap Viskositas Natrium Alginat yang Diekstrak dari Sargassum duplicatum J.G. Agardh (Phaeophyta). Oseanologi dan Limnologi di Indonesia (33): 295306.

Yunisa, S. 2007. Isolasi Asam Alginat dari Ganggang Coklat (Sargassum crassifolium J.Agard) Menggunakan Natrium Karbonat 7\%. Skripsi. Fakultas Farmasi. Universitas Andalas. Padang. 